\title{
Pedagogical variation with computers in mathematics classrooms: A Cultural Historical Activity Theory analysis
}

\begin{abstract}
South Africa's crisis in mathematics attainment is well documented (DBE, 2013; Spaull, 2014; WEF, 2014). To meet the need to develop students' mathematical performance in schools the government has launched various initiatives using computers to impact on mathematical attainment. While it is clear that computers can change pedagogical practices, there is a dearth of qualitative studies indicating exactly how pedagogy is transformed with Information Communication Technologies (ICTS) in a teaching activity. Consequently, this paper addresses the following question: how, along which dimensions in an activity, does pedagogy alter with the use of computer drill and practice software in four disadvantaged grade 6 mathematics classrooms in the Western Cape province of South Africa? The paper draws on Cultural Historical Activity Theory (CHAT) to develop a view of pedagogy as socially situated. Four ideal pedagogical types are identified: Reinforcement pedagogy, which has the reinforcement of specialised knowledge as its object; Collaborative pedagogy, which has the development of metacognitive engagement with specialised knowledge as its object; Directive pedagogy, which has the development of technical task skills as its object, and finally, Defensive pedagogy, which has student regulation as its object. Face-to-face lessons were characterised as predominantly Reinforcement and Collaborative pedagogy and most computer lessons were characterised as mainly either Defensive or Directive.
\end{abstract}

\section{Introduction}

South Africa continues to face an educational crisis especially in mathematics and science attainment (WEF, 2013; Spaull, 2014). In a bid to meet this challenge, the

\section{Joanne Hardman}

School of Education, University of Cape Town, Rondebosch, Cape Town joanne.hardman@uct.ac.za

\section{Keywords:}

cultural historical activity theory, pedagogy, teaching with computers, pedagogical modes, primary school mathematics 
government has launched numerous initiatives using ICTs in schools in order to impact positively on students' performance. The introduction of computer software to improve mathematical performance is informed by a well-established relationship between learning outcomes and learning resources (Schollar, 2001). One such initiative is the Khanya project in the Western Cape Province of South Africa. This is a province-wide initiative involving a number of primary and secondary schools which aims to "promote learning and maximise educator capacity by integrating the use of appropriate, available and affordable technology into the curriculum process" (Khanya, 2001: 1). All project schools receive a computer laboratory equipped with sufficient computers so that no more than two children need to work at a computer at any one time. A computer is allotted to the teacher, and is networked to the other computers in the classroom. Connectivity is ensured, but schools are required to pay their internet bill, which constrains internet use. This study is located in 4 such Khanya project schools in previously disadvantaged areas of the Western Cape, South Africa. While most research that investigates computers in schools concerns itself primarily with the impact the computer software has on learning rather than focusing on teaching (Cox and Abbott, 2004), this paper focuses very specifically on teaching in order to address the question of how, across what dimensions, pedagogy potentially alters with the introduction of computer software into grade 6 mathematics classrooms. The question arises out of prior research where, 1 ) it was shown that there is a statically significant difference between the type of talk used in face to face and computer based mathematics classrooms (Hardman, 2014) and,2) research conducted by the researcher and her colleague indicates that there is no statistically significant difference in attainment of mathematics marks when using computer software (namely MasterMaths) to teach mathematics in the Western Cape (SpencerSmith \& Hardman, 2014). While there is little argument in psychological and educational settings about the primacy of teachers in developing students' knowledge, surprisingly few Information and Communication Technologies (ICTs) studies focus exclusively on pedagogy with computers (for exceptions to this see Becta, 2000; 2001; 2007).

\section{Pedagogy and psychology}

"Pedagogics is never and was never politically indifferent, since, willingly or unwillingly, through its own work on the psyche, it has always adopted a particular social pattern, political line, in accordance with the dominant social class that has guided its interests" (Vygotsky, 1997b: 348).

This quote from Vygotsky points to the importance of understanding pedagogy in the socio-political context in which it unfolds. This is especially important in a context such as South Africa which has emerged relatively recently (1994) from a political regime that systematically undereducated the majority of the population. Seeking to undo the tremendous damage done by the Bantu education system under Apartheid, one of

PINS [Psychology in Society] 48 • $2015 \mid 48$ 
the first policy initiatives of the new government was to redress educational inequality. While the link between socio-cultural conditions and pedagogy are evident in the above quote, the link between psychology and pedagogy might not seem, at first sight, to be of import. However, what happens at the micro-level of the classroom is crucial to the developmental trajectory of each child. For Vygotsky (1978) higher cognitive functions, those things like drawing, art, music and language, which make us uniquely human, are mediated by others; very specifically, the school is the site of most of our induction into scientific concepts that are formative of our personal development. One of the real strengths of CHAT, I would argue, lies in its ability to subvert traditional, classical logical thinking that sets up dichotomies of intra/inter psychological; individual/society, psychological/sociological and cognitive/emotive. The dialectical logic underpinning CHAT allows us to move away from the more traditional Western psychological logic that tends to rely on binary thinking.

\section{Pedagogical change with computers: Division of labour and object}

One of the most persistently recorded findings regarding pedagogical variation with computer use relates to the fact that constructivist software potentially opens up collaborative interaction between students and, consequently, impacts on division of labour within a classroom. For Underwood and Underwood $(1990 ; 1999)$ the computerbased environment opens up a space for students to co-operate in order to solve problems and work collaboratively. This is also picked up by Wegeriff and colleagues' work with dialogic enquiry that shows that the computer can open up spaces for students to engage in collaborative dialogue to solve problems (Wegeriff \& Dawes, 1997; Wegeriff \& Mercer, 1997; Wegeriff \& Scrimshaw, 1997). The argument here is that the constructivist nature of the software coupled with small group work provides students with more opportunities to collaborate than in face-to-face lessons, shifting the teacher's role to one of facilitator and the student role to one of peer teacher, ultimately developing more autonomous students (Hoyles \& Sutherland, 1989; Underwood \& Underwood, 1999; Kozma \& Anderson, 2002; Ilomäki, Lakkala \& Lehtinen, 2004; Paavola, \& Hakkarainen, 2005; Veermans, \& Cesareni, 2005a; Veermans, Lallimo, \& Hakkarainen, 2005b; llomäki, Lakkala \& Paavola, 2006).

In an investigation into how power relations play out in the context of computer innovation in classrooms, Garrison and Bromley (2004) study how the social context largely determines how computers will be used in a classroom. They distinguish a mode of teaching that is concerned primarily with maintaining control, which they, following McNeil (1986) call "defensive teaching". This kind of teaching, they point out, is often found in schools with students from predominantly working class backgrounds who are antagonistic to school knowledge (Ogbu, 1987). Defensive teaching has two varieties. In the one instance teachers rigidly control students' actions by giving them step-by-step 
instructions even when it is clear that the students are able to engage with the computer without instruction. In the second instance, teachers use the computer as a reward/ punishment, using it to motivate students as well as to discipline them by, for example, threatening to withhold computer use from students who are disobedient. The authors point out that defensive teaching occurs in the presence and absence of technology.

Changes in teacher and student roles in the computer-based lesson potentially impact on what is being worked on in the classroom. Research regarding how the object of pedagogy in a mathematics classroom shifts with the use of a computer is varied. The notion of "object" in CHAT is critical, as it is that space that is transformed during the activity - what Engestrom (1987) calls the problem space that is worked on and altered into an outcome. It also contains the motive for acting in the activity (Leontiev, 1981). Identification of the object in an activity is crucial for mapping the activity system(s). While the large-scale, in depth, longitudinal ImpaCT2 (2001) study cautions that the use of computers may lead to a focus on lower-order, basic mathematical skills, this is contradicted by findings from research into Logo, a computer programme based on Piagetian principles of cognitive constructivism, with autonomous students who use Logo demonstrating a superior conceptual understanding of algebra and geometry compared to those receiving traditional instruction (Au \& Leung, 1991; Campbell et al, 1991; Yelland, 2003). For Hakkarainen (2003; 2004) computers enable students to engage in progressive enquiry that leads to expansive learning, which is characterised by the creation of new tools to engage with problem solving. It moves students from learning to use established tools to designing and developing novel tools. The object of a learning activity then becomes "the generation and use of knowledge" (Miettinen, 1999: 333). Here "expansive learning" refers to learning that leads to an entirely new activity system, with a new object, or problem space. That is, the use of tools, such as language or indeed the computer software, can lead to shifts in the object of the activity, leading to a new kind of learning which is characterised as expansive in that it leads to new concepts, new agency and a new way of acting in the new activity system. Much of the learning we see in schools cannot be characterised as expansive, because, quite simply, it does not lead to new a new activity but merely a reproduction of knowledge. However, the possibility exists that introducing a novel tool, such as a computer into a classroom, can indeed lead to a transformation in the activity. It is this possibility that informs the current paper. Investigating the computer software's potential for developing higher order reasoning, Mercer and his colleagues in the Spoken Language and New Technology project (SLANT) team have done extensive research to show how the computer-based environment potentially develops students' reasoning skills through developing exploratory talk, and how children learn collaboratively with computers using specific types of talk. According to Mercer and his colleagues, exploratory talk, which is characterised by joint problem solving, reflection, and constructive criticism in which students are encouraged to challenge their peers constructively through offering alternative hypotheses, develops students' reasoning skills (Mercer \& Fisher, 1997a; 1997b; Wegerif \& 
Mercer, 1997c; Wegerif, 1997a; Wegerif \& Scrimshaw, 1997c; Wegerif \& Dawes, 1997; Mercer \& Wegeriff, 1998; Mercer, Wegerif \& Dawes, 1999; Mercer, 2000a; Mercer, 2000b). This research mentioned above, therefore, suggests that, given the right training and software, students' thinking can be developed in the computer-based environment. In the current study, CAMI maths software was used in the lessons. Essentially a drill and practice type software, this programme does, however, allow for scaffolded engagement and individualised pacing which could, under the optimal conditions, lend itself to the development of higher order mathematical thinking. This begs the question of what such 'optimal' conditions might be; in this study, such conditions might be the teacher allowing students to explore the software and work at their own pace to solve problems. As we shall see, this is not how the software was predominantly used in this study.

A higher order object, such as learning of mathematics, is not the only object that the computer can be used to act on. In a tertiary environment, Russell (2002) has shown that the computer itself and the technical skills required to use the computer could well be the object of the computer-based lesson, especially in the early phases of computer use. At the primary school educational level Hardman $(2005 ; 2007)$ has echoed Russell's findings pointing out that the object of computer based maths lessons is very often a narrow, lower order object and, in many instances is in fact the computer itself.

\section{Pedagogical change with computers: The computer as tool}

In the current study, tool use is viewed from a CHAT standpoint as both altering the world and the user. For Vygotsky (1978) the primary cognitive tool that is the tool that alters one's thinking and leads to higher cognitive functioning, is language. In CHAT, however (see Cole, 1996), tools can be seen as material tools too, which carry with them a history of use and cultural meanings. That is, the computer, for example, has a history of use that is intertwined with cultural practices of use. In this field, Saljo's (1999) work highlights the importance of viewing the computer as a tool that can be used to alter a student cognitively. How one uses a computer, the cultural setting of computer usage, can transform how one thinks. As a cognitive tool, the computer can potentially transform thinking from lower levels to higher cognitive functioning. Developing the notion of the computer as a tool, Hokanson and Hooper (2000) draw a distinction between whether a computer is used as a representation tool, which merely represents known information in a different medium and "transmits information", or whether it is used as a generative tool to develop novel knowledge and improve "the capability to generate thought" because it is used for "knowledge construction" (Hokanson \& Hooper, 2000: 543; 547). The authors indicate that media use falls on a continuum from representational to generative and they give examples of such use in a mathematics classroom where the use of a calculator to "solve repetitive problems" is seen as representative use and "solving complex real life problems, e.g. word problems" (ibid: 549), such as in the Cobb and McClain's (2002) study 
for example, is viewed as generative use. For the authors, the value of the computer is to be found in its generative rather than representative capacities.

In summary, using the computer as a tool in a classroom transforms pedagogical practices by impacting on division of labour and the object of the activity, with teachers and students taking on different roles in this context. This paper locates itself firmly with a Cultural Historical Activity Theory (CHAT) framework, which views the computer as a tool capable of acting on an object of an activity and transforming it into an outcome.

\section{Theoretical framework}

This paper draws on the broad field of CHAT to situate pedagogical practices in context. Finding its genesis in the work of Vygotsky $(1978 ; 1986)$, CHAT holds that higher cognitive functions are necessarily mediated by signs/tools. Moving from the purely Vygotskian focus on language as the primary mediating tool, Engeström (1987) has developed a model of human activity that situates mediation in a broader social context. It is this model that informs the analysis presented in this paper. Figure 1 illustrates the basic unit of analysis (an activity system) proposed by Engeström (1987).

\section{Figure 1. Activity System}

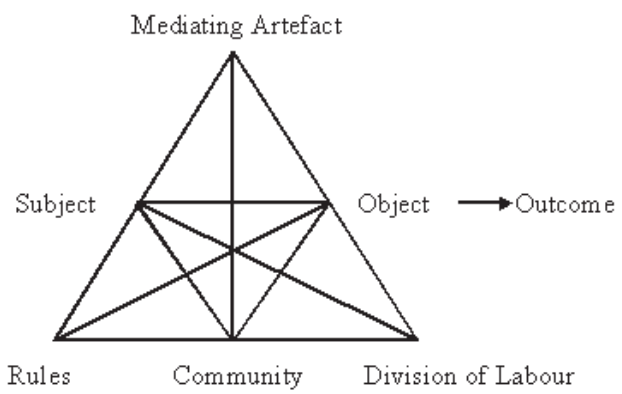

Figure 1 shows the basic unit of an activity system indicating that the subject(s) acts on the object in order to transform it using mediating artefacts in order to arrive at specific outcomes. In turn, the subject's position is influenced by the rules of the system, the community and division of labour (how the context is organised: this refers also to vertical and horizontal division of labour) (Engeström, 1987; 1991; 1996; 1999). So in a classroom, for example, the subject is the teacher who acts on the object of the activity (which in this paper is assumed to be the learning of mathematics) using tools, such as language and the computer in a context where there are different roles (division of labour) and rules (which afford and constrain behaviour- such as the rule to put up one's hand when asking the teacher a question). The community is that group of 
people who share a common object- that is, it is not a broad community, but rather the narrow community that is focused on a specific object that they share. In the instance of this paper, the community would include only teacher and students, as parents, for example, do not participate in this shared object (note however, that in some research sites parents may well participate in sharing the object of mathematics learning- this is not the case in this paper, however).

Figure 2. Third generation activity theory

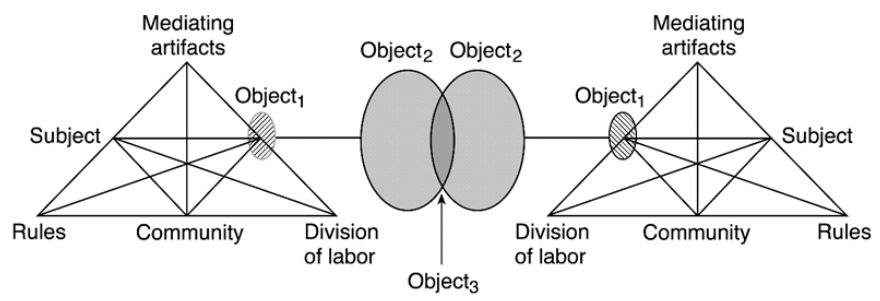

Figure 2 illustrates that an activity system never operates in isolation but is always part of a wider network of activities. In this expanded version of Leontiev's work (referred to as second generation activity theory), the individual action represented at the pinnacle of the triangle is situated within a context in which power relations and rules impact on the subject's actions (Wells, 1999). This allows for a nuanced view of human activity as dialectical, both social and individual, with neither individual nor social serving as a starting point for explaining the other (Roth \& Lee, 2007). It is this version of CHAT as articulated by Engeström (1987) and Cole (1996) that I draw on in this paper. It is important to note that CHAT incorporates a diverse field of researchers and many do not draw on the notion of activity system triangles in their work (see for example Stesenko, 2013; Fleer, 2008; Ridgeway, 2015) CHAT is a broad umbrella term that refers to work that finds its etiology ultimately in the cultural historical work of Vygotsky (1978). To avoid confusion, for the purposes of this paper CHAT is utilised to refer to the work of Cole (1996) and specifically the human activity model of Engeström (1987) that arises out of a historical development of Leontiev's (1981) focus on practical as opposed to simply semiotic activity as developmentally central.

For Engeström (1987) an activity unfolds over time and is not generally equated with something as brief as a lesson that unfolds in a school (Roth \& Lee, 2007). However, there does not, in my reading of his work, appear to be a theoretical objection to the use of Engeström's systems thinking to study practice that unfolds over the period of a lesson, as in this study. So Engeström's work provides a view of practice as socially situated, where the social context is elaborated as an activity system. 


\section{Participants}

Four schools (Merryvale, Newton, Thandokhulu, and Siyazama) that routinely use technology to teach mathematics were identified from the Western Cape Education Department's (WCED) Khanya project initiative, which saw the roll out of computers into disadvantaged schools in the Western Cape over a 10 year period. Here "routine" refers to the use of computers to teach mathematics at least once a week. The four schools were selected because 1) they had good infrastructure- where this refers to a teaching body that attends lessons; a principal that leads the school and is committed to the use of technology in teaching, and 2) because they had just begun the roll out of technology in their classes. That is, they were introducing a novel tool into an established practice of teaching. Four teachers who specialise in teaching mathematics were selected to participate in the study. Teachers were selected on the basis that they consented to the research over the period of a year. All four teachers are Afrikaans first language speakers, although only one teacher actually teaches in Afrikaans. All names used in this paper are pseudonyms. Only one teacher in the study, Ms Todd, had a university degree. Only Mr Botha had a computer at home. The other teachers had to do their computer lesson preparation at school rather than at home. Mrs De Wet and Mr Botha only taught grade 6 and 7 . Unlike most primary school teachers who teach all levels, these teachers focused their attention on the final two years of primary school.

\section{Research design and methodology}

The study adopted a case study design in order to understand how teachers teach in the presence of computers and, relatedly, how or whether their pedagogy shifted across contexts (Yin, 1984). While a variety of data collection methods were utilised ranging from demographic questionnaires and interviews to classroom observations and video data of classroom practice, this paper reports on the video data gathered over the period of a year in four schools in the Western Cape. Data were collected using video to ensure that the nuances of pedagogical interaction were collected in a form that could be transcribed and analysed. The data collected were in English and Afrikaans. The Afrikaans data were translated by an Afrikaans first language grade 6 teacher with 15 years experience teaching at this level. Four teachers and their students were observed for the period of a year in face to face and computer based mathematics lessons. Pedagogical practices were compared across face to face and computer based lessons. Analysis of observational data involved sampling from the data using evaluative episodes (described below) before analysis was undertaken.

- The first stage involved developing a sampling mechanism capable of selecting episodes in the data that highlighted the object of the activity. A selection mechanism, which I term evaluative episodes, is used to 1) select episodes from classroom interactions to analyse in more depth; 2) elicit the object of the episode in the absence of direct intervention; and 3) provide an analytical space to investigate tools, rules, division of labour, object and outcome. An evaluative 
episode is a coherent classroom activity in which the teacher elaborates the evaluative criteria required to produce a legitimate pedagogical script. This refers to the production of work that is recognised, in the local classroom context, as correct by the teacher. Note, however, that a script that is recognised as legitimate by the teacher in the classroom might not be considered legitimate in relation to the wider mathematical field. These episodes are marked out because they represent disruptions in the intended pedagogical script. That is, they indicate a break in the flow of the pedagogic plan where the teacher is called on to restate and make explicit the requisite evaluative criteria in response to student productions (Hardman, 2005a; 2005b; 2007a; $2007 \mathrm{~b})$. The reference to disruptions and restatement of content draws on the body of knowledge that has developed out of Flanagan's (1954: 33) definition of a critical incident as "a classroom episode or event which causes a teacher to stop short and think" as well as Wragg's (2001: 11) description of a critical incident as an event that appears to "help or impede children's understanding", and Goodwin's (2001: 11) understanding of these events as turning points in the lesson "where the teacher's utterances influence the shape and tone of the subsequent interaction".

- Secondly, once episodes were identified, teacher and student talk in these evaluative episodes was coded, using codes which were developed iteratively using the work of Wells (1999) and Mercer (2005) in relation to the empirical data. These codes are presented in Table 1 below.

- Thirdly, a CHAT coding schedule, which draws on the coding carried out in the second stage of the analysis, was designed to analyse each episode as a whole by assigning numerical values to tool use, rules, object and division of labour on a Likert-type scale. This research uses a Likert-type scale to analyse pedagogical practices along a continuum. This is not an actual Likert scale because respondents are not asked to select a response to a given statement. Rather, the researcher observes pedagogical practices and assigns a value to these practices. I note that this is not how Engeström mobilises his framework. For Engeström, who studies expansive learning, a set methodology called a Change Laboratory (1999) is used to identify expansive cycles of learning, predominantly in the work place. In this paper, however, reducing the complexity of classroom level data was deemed necessary and hence a coding schedule was designed to do so (for more detail on this see Hardman, 2008). 
Table 1. Coding of talk

\begin{tabular}{|c|c|c|c|}
\hline Tool & Code & Description & Empirical Example \\
\hline \multirow[t]{2}{*}{$\begin{array}{l}\text { Mathematical } \\
\text { content } \\
\text { statement }\end{array}$} & $\begin{array}{l}\text { M1: with no } \\
\text { elaboration }\end{array}$ & $\begin{array}{l}\text { Mathematical } \\
\text { statements with no } \\
\text { elaboration }\end{array}$ & $\begin{array}{l}\text { Teacher: When I say simplify this means make the } \\
\text { fraction simple. Then you don't have problems } \\
\text { with big numbers because you all can't do your } \\
\text { tables! }\end{array}$ \\
\hline & $\begin{array}{l}\text { M2: With } \\
\text { elaboration }\end{array}$ & $\begin{array}{l}\text { Elaboration of how } \\
\text { and why one solves } \\
\text { maths problems } \\
\text { using a variety } \\
\text { of scaffolding } \\
\text { techniques. }\end{array}$ & $\begin{array}{l}\text { Teacher: Remember, the reason you must times } \\
\text { the denominator's here is because you timesed } \\
\text { the numerators. What you do to the numerator } \\
\text { you do to the denominator. }\end{array}$ \\
\hline \multirow[t]{3}{*}{ Math questions } & $\begin{array}{l}\text { QM1: testing } \\
\text { questions }\end{array}$ & $\begin{array}{l}\text { Used solely to } \\
\text { assess knowledge } \\
\text { base and not to } \\
\text { open teaching } \\
\text { interaction; closed } \\
\text { in nature. }\end{array}$ & $\begin{array}{l}\text { Teacher: Right } 5 \text { x } 3 \text { please (points to a boy in the } \\
\text { first desk) } \\
\text { Sipho: } 15 \\
\text { Teacher: plus } 2 \text { ? Points to student } 2 \\
\text { Bongani: } 17 \\
\text { Teacher: minus } 3 \text { Points to a girl in the desk oppo- } \\
\text { site the boy, he is working his way around the class. } \\
\text { Shilpa: no answer }\end{array}$ \\
\hline & $\begin{array}{l}\text { QM2: Teach- } \\
\text { ing questions }\end{array}$ & $\begin{array}{l}\text { Open interaction } \\
\text { by scaffolding stu- } \\
\text { dents' engagement } \\
\text { with the content } \\
\text { under investiga- } \\
\text { tion: leading chil- } \\
\text { dren from known } \\
\text { to novel knowledge } \\
\text { in a structured and } \\
\text { guided manner. }\end{array}$ & $\begin{array}{l}\text { Teacher: What does equivalent mean? } \\
\text { Students: equal } \\
\text { Teacher: ok, equal value so if I have } 1 / 2 \text { who can } \\
\text { tell me what's equal to } 1 \frac{12}{2} \text { ? The teacher goes on to } \\
\text { elaborate a pattern that will help students solve } \\
\text { equivalent fractions. She uses questions to lead } \\
\text { students, in a step by step process, to the correct } \\
\text { answers. }\end{array}$ \\
\hline & $\begin{array}{l}\text { QM3: Probing } \\
\text { questions }\end{array}$ & $\begin{array}{l}\text { 'Why' questions } \\
\text { requiring reflective } \\
\text { engagement. }\end{array}$ & Teacher: Why do you say $1 / 2 \times 1 / 2$ is equals to a $1 / 4$ ? \\
\hline $\begin{array}{l}\text { Technical Task } \\
\text { skills }\end{array}$ & $\begin{array}{l}\text { TM1: task } \\
\text { skills }\end{array}$ & $\begin{array}{l}\text { These are technical } \\
\text { skills that the } \\
\text { student learns } \\
\text { in order to use } \\
\text { novel technology } \\
\text { successfully. }\end{array}$ & Teacher: Click there. Right click. Or double click. \\
\hline
\end{tabular}


Table 1. Coding of talk...continued

\begin{tabular}{|c|c|c|c|}
\hline Rules & Code & Description & Example \\
\hline \multirow[t]{2}{*}{$\begin{array}{l}\text { Instructional: } \\
\text { Evaluative rules }\end{array}$} & $\begin{array}{l}\text { F1: no } \\
\text { elaboration }\end{array}$ & $\begin{array}{l}\text { No explanation is } \\
\text { given regarding } \\
\text { why a student's } \\
\text { response is right/ } \\
\text { wrong. This catego- } \\
\text { ry only arises in re- } \\
\text { sponse to students' } \\
\text { productions. }\end{array}$ & $\begin{array}{l}\text { Teacher: } 1 / 2 \text { plus } 1 / 2 \text { is not } 1 / 4 \text {. That answer is wrong. } \\
\text { Teacher moves away from student to look at the } \\
\text { next computer screen. }\end{array}$ \\
\hline & $\begin{array}{l}\text { F2: with } \\
\text { elaboration }\end{array}$ & $\begin{array}{l}\text { The teacher tells } \\
\text { students why } \\
\text { their answers are } \\
\text { incorrect and, } \\
\text { therefore, gives } \\
\text { them an indication } \\
\text { of how one goes } \\
\text { about producing a } \\
\text { legitimate mathe- } \\
\text { matical text. }\end{array}$ & $\begin{array}{l}\text { Teacher: So how do we add } 1 / 2 \text { plus } 1 / 2 \text { ? What is our } \\
\text { answer? Jack: A quarter. Teacher: ok, let's do this } \\
\text { together. We take } 1 / 2 \text { and add it with another } 1 / 2 \\
\text { (teacher picks up the two halves of the apple that } \\
\text { he cut earlier and begins to explain how he arrives } \\
\text { at his answer). }\end{array}$ \\
\hline Pacing & $\begin{array}{l}\text { P1: pacing: } \\
\text { high versus } \\
\text { low teacher } \\
\text { control }\end{array}$ & $\begin{array}{l}\text { Overt verbal con- } \\
\text { trol over pacing. }\end{array}$ & $\begin{array}{l}\text { Teacher: Hurry, faster. Time is short! } \\
\text { Everyone together. }\end{array}$ \\
\hline \multirow[t]{2}{*}{ Social order } & $\begin{array}{l}\text { S1: } \\
\text { behavioural } \\
\text { prescriptions: } \\
\text { disciplinary } \\
\text { norms }\end{array}$ & $\begin{array}{l}\text { Teacher tells } \\
\text { children how to } \\
\text { behave. }\end{array}$ & $\begin{array}{l}\text { Teacher: You put up your hand when you } \\
\text { want to talk. It's just respect, people! }\end{array}$ \\
\hline & $\begin{array}{l}\text { S2: } \\
\text { communica- } \\
\text { tion relations }\end{array}$ & $\begin{array}{l}\text { Refers to who } \\
\text { controls commu- } \\
\text { nication in the } \\
\text { lesson indicating } \\
\text { the extent to which } \\
\text { students have ac- } \\
\text { cess to pedagogical } \\
\text { discourse in the } \\
\text { lesson. Judged by } \\
\text { coding teacher and } \\
\text { student discourse. }\end{array}$ & $\begin{array}{l}\text { This category entails quantification } \\
\text { of the discourse. }\end{array}$ \\
\hline
\end{tabular}


The data collected for this research were utterances, that is, verbal utterances that could stand alone as meaningful units of speech. On the far left of the table the type of linguistic tool and rule is identified and given a code. The definition of the code and an exemplar of this type of utterance are provided from the empirical data set. There are two types of linguistic tools used. First, questions and statements are used to elaborate mathematical content knowledge and second, statements are used to elaborate task skills. In this paper the focus is exclusively on verbally encoded rules because of the type of data available in the evaluative episodes. This is not to suggest that non-verbal rules are absent from the episodes, however, this is not the focus of the current analysis. Verbal rules are divided into two types: social order rules and instructional rules, which are in turn divided into further sub-categories. Instructional rules are divided into two subcategories: evaluative rules and pacing rules. Social order rules are divided into the subcategories of disciplinary norms and communication relations. This elaboration of rules comes from a Bernsteinian (1977) framework where reference is made to instructional and social order rules. These have been operationalised in the current paper in relation to the sub categories of evaluative and pacing rules (rules of the instructional kind) and disciplinary norms and communication relations (rules of the social order). Empirically, rules and division of labour are not separable but are dynamically interrelated; rules maintain roles through control relations and power relations (roles) are enacted through rule-governed behaviour; however, I have analytically separated these categories. The codes in Table 1 are assigned to utterances in an evaluative episode and are then counted to generate a picture of frequency of codes across the episode as a whole. In the case of this paper, an utterance is identified with a clause. Frequency counts enable one to derive percentages of utterances in relation to the episode as a whole.

The coding of utterances outlined above served to refine the development of a CHAT coding schedule. Drawing on the CHAT concepts of tools, rules, division of labour, object, and outcomes, 19 indicators were identified with which to analyse the 28 evaluative episodes. So for example, if we look at how tools are analysed in an episode as outlined in Table 2 we can see how data are captured. 
Table 2: Analysing tools with the AT coding schedule

\begin{tabular}{|c|c|c|c|c|c|c|}
\hline \multicolumn{3}{|c|}{ Level one } & \multicolumn{2}{|c|}{ Restricted } & \multicolumn{2}{|c|}{ Elaborated } \\
\hline \multirow[t]{9}{*}{ Tools } & \multirow[t]{3}{*}{$\begin{array}{l}\text { Linguistic } \\
\text { tools }\end{array}$} & $\begin{array}{l}\text { 1. Statements transmitting mathematical } \\
\text { content } M 1^{\star} \& M 2\end{array}$ & 1 & 2 & 3 & 4 \\
\hline & & 2. Mathematical content questions QM1, QM2, QM3 & & & & \\
\hline & & 3. Statements transmitting task skills TM1 & & & & \\
\hline & \multirow{6}{*}{$\begin{array}{l}\text { Non-linguistic } \\
\text { tools }\end{array}$} & 4. Blackboard: generative use & & & & \\
\hline & & 5. Blackboard: representational use & & & & \\
\hline & & 6. Computer: generative & & & & \\
\hline & & 7. Computer representational use & & & & \\
\hline & & 8. Other: generative use & & & & \\
\hline & & 9. Other: representational use & & & & \\
\hline
\end{tabular}

* These codes are elaborated above.

Data are captured on a four-point Likert-type scale ranging from one to four; for tool use, this scale refers to whether the tool is used to elaborate mathematical knowledge [3-4] or restrict it [1-2] and is judged by investigating the percentage of teacher talk used to elaborate mathematics in the episode. In a bid to reduce inference bias when using the schedule, a decision was taken to code utterances and count them, generating a frequency count for various types of utterances encoding various aspects of the CHAT dimensions of tool, rule, division of labour, object, and community. Hence, rather than using a traditional Likert scale which refers to potentially ambiguous terms such as "a little" or "most", the schedule tries to mitigate inference effects by referring to actual percentages of utterances. So where $76 \%$ of a teacher's utterances elaborate mathematical content this would be captured as [4] in term of the following descriptors outlined in Table 3.

Table 3. Linguistic tools: Mathematical content statements

\begin{tabular}{|l|l|l|l|}
\hline TOOLS & \multicolumn{2}{|l|}{ Linguistic tools } \\
\hline Indicator & Mathematical content statements \\
\hline $\begin{array}{l}\text { 1 Most Restricted } \\
\text { Principles and } \\
\text { procedures implicit }\end{array}$ & 2 Moderately restricted & $\mathbf{3}$ Moderately elaborated & $\begin{array}{l}\text { 4 Most elaborated } \\
\text { Principles and } \\
\text { procedures explicit }\end{array}$ \\
\hline $\begin{array}{l}\text { 0-24\% of teachers' } \\
\text { discourse explicates/ } \\
\text { elaborates } \\
\text { mathematical content. }\end{array}$ & $\begin{array}{l}\text { 25-49\% of teachers' } \\
\text { discourse explicates/ } \\
\text { elaborates mathematical } \\
\text { content. }\end{array}$ & $\begin{array}{l}\text { 50-75\% of teachers' } \\
\text { discourse explicates/ } \\
\text { elaborates mathematical } \\
\text { content. }\end{array}$ & $\begin{array}{l}\text { 76-100\% of teachers' } \\
\text { discourse elaborates } \\
\text { mathematical content. }\end{array}$ \\
\hline
\end{tabular}


The final coding schedule used to analyse the episodes is represented in Table 4 (below). 28 evaluative episodes were identified across 22 hours of teaching time. These episodes were then analysed using the schedule outlined in Table 4 and four broad patterns of tool use, rules, community, object, division of labour, and outcomes were identified. These patterns are discussed in the findings as pedagogical modes.

Table 4. The AT coding schedule

\begin{tabular}{|c|c|c|c|c|c|c|c|}
\hline \multirow{2}{*}{\multicolumn{4}{|c|}{ Level one }} & \multicolumn{2}{|c|}{ Restricted } & \multicolumn{2}{|c|}{ Elaborated } \\
\hline & & & & \multirow{2}{*}{1} & \multirow{2}{*}{2} & \multirow{2}{*}{3} & \multirow{2}{*}{4} \\
\hline Tools & \multirow{3}{*}{\multicolumn{2}{|c|}{ Linguistic tools }} & $\begin{array}{l}\text { Statements transmitting } \\
\text { mathematical content }\end{array}$ & & & & \\
\hline & & & $\begin{array}{l}\text { Questions transmitting } \\
\text { mathematical content }\end{array}$ & & & & \\
\hline & & & $\begin{array}{l}\text { Statements transmitting } \\
\text { task skills }\end{array}$ & & & & \\
\hline & \multirow{6}{*}{\multicolumn{2}{|c|}{ Non-linguistic tools }} & Blackboard: generative use & & & & \\
\hline & & & $\begin{array}{l}\text { Blackboard: } \\
\text { representational use }\end{array}$ & & & & \\
\hline & & & Computer: generative & & & & \\
\hline & & & $\begin{array}{l}\text { Computer } \\
\text { representational use }\end{array}$ & & & & \\
\hline & & & Other: generative use & & & & \\
\hline & & & Other: representational use & & & & \\
\hline \multirow[t]{7}{*}{ Rules } & \multirow[t]{3}{*}{ Instructional } & Evaluative & $\begin{array}{l}\text { Evaluation } \\
\text { of students' productions: } \\
\text { explicit vs. implicit }\end{array}$ & & & & \\
\hline & & & & \multicolumn{2}{|c|}{$\begin{array}{l}\text { Low teacher } \\
\text { control }\end{array}$} & \multicolumn{2}{|c|}{$\begin{array}{l}\text { High teacher } \\
\text { control }\end{array}$} \\
\hline & & Pacing & Time on task & & & & \\
\hline & \multirow[t]{4}{*}{ Social order } & Order/ Discipline & Classroom management & & & & \\
\hline & & \multirow{3}{*}{$\begin{array}{l}\text { Communication } \\
\text { relations }\end{array}$} & Teacher-learner talk time & & & & \\
\hline & & & Teacher questioning & & & & \\
\hline & & & $\begin{array}{l}\text { Questioning to promote } \\
\text { interaction }\end{array}$ & & & & \\
\hline \multirow{2}{*}{\multicolumn{3}{|c|}{ Object }} & & \multicolumn{2}{|c|}{ Localised } & \multicolumn{2}{|c|}{ Specialised } \\
\hline & & & Focus of episode & & & & \\
\hline
\end{tabular}


Table 4. The AT coding schedule...continued

\begin{tabular}{|c|c|c|c|c|c|c|}
\hline \multicolumn{3}{|l|}{ Level two } & \multicolumn{2}{|c|}{$\begin{array}{l}\text { Symmetrical } \\
\text { power }\end{array}$} & \multicolumn{2}{|c|}{$\begin{array}{l}\text { Asymmetrical } \\
\text { power }\end{array}$} \\
\hline \multirow[t]{3}{*}{$\begin{array}{l}\text { Division of } \\
\text { labour }\end{array}$} & Non-linguistic & $\begin{array}{l}\text { Strength of boundaries } \\
\text { between teaching and } \\
\text { learning spaces }\end{array}$ & & & & \\
\hline & \multirow[t]{2}{*}{ Linguistic } & $\begin{array}{l}\text { Teacher student interaction: } \\
\text { teacher roles }\end{array}$ & & & & \\
\hline & & $\begin{array}{l}\text { Teacher student interaction: } \\
\text { student roles }\end{array}$ & & & & \\
\hline \multirow[t]{2}{*}{ Outcome } & & & 1 & 2 & 3 & 4 \\
\hline & & Type of object & & & & \\
\hline
\end{tabular}

\section{Findings}

Four ideal types of pedagogical practices emerged in the findings: collaborative, reinforcement, directive and defensive pedagogical practices. There are ideal types and should not be seen as located in any one teacher; one teacher may use more than one type of pedagogy in any given lesson. All pedagogical types differed across the activity system dimensions outlined by Engeström: subject, object, mediating artefact, community, rules and division of labour.

The first and most prevalent type of practice identified in the data, sees the teacher acting in the role of instructor, using language and material tools to develop and reinforce students' subject content knowledge in a context in which evaluative rules are elaborated and rules of pacing and the social order are not firmly controlled by the teacher. This pattern of interaction is illustrated in Table 5 below. This pattern emerged through analysing similarities and differences across episodes. Those episodes with similar patterns of practice along the AT dimensions were grouped together to identify pedagogical types. 


\begin{tabular}{|c|c|c|c|c|c|c|c|c|c|c|c|c|c|c|c|}
\hline 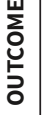 & \multicolumn{2}{|l|}{ 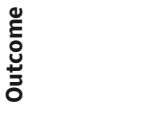 } & $m$ & $m$ & $m$ & $m$ & $m$ & $m$ & $m$ & $m$ & $m$ & $m$ & $m$ & $m$ & $m$ \\
\hline 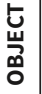 & \multicolumn{2}{|l|}{$\begin{array}{l}\stackrel{\breve{d}}{\circ} \\
\stackrel{0}{\circ}\end{array}$} & $m$ & $m$ & $m$ & $m$ & $m$ & $m$ & $m$ & $m$ & $m$ & $m$ & $m$ & $m$ & $m$ \\
\hline 号 & \multicolumn{2}{|l|}{$\begin{array}{l}\stackrel{\Xi}{0} \\
\text { ñ }\end{array}$} & $\sigma$ & $\nabla$ & 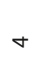 & $\nabla$ & $\nabla$ & $\nabla$ & $\nabla$ & $\nabla$ & $\nabla$ & $\nabla$ & $\sigma$ & $\nabla$ & $N$ \\
\hline $\begin{array}{l}\text { 山े } \\
\text { u } \\
z \\
0\end{array}$ & \multicolumn{2}{|l|}{ 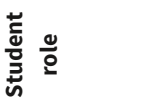 } & $\neg$ & -1 & $m$ & -1 & $m$ & -1 & $\nabla$ & $m$ & $m$ & $m$ & $m$ & $m$ & $m$ \\
\hline$\frac{10}{\Delta}$ & \multicolumn{2}{|l|}{ 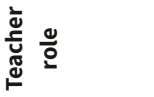 } & $N$ & $N$ & $\sim$ & $N$ & $N$ & $N$ & $N$ & $\sim$ & $N$ & $N$ & $\sim$ & $N$ & $N$ \\
\hline & \multicolumn{2}{|l|}{ 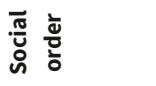 } & $\sim$ & $N$ & $\sim$ & $N$ & & $\sim$ & $N$ & $N$ & $\sim$ & $N$ & $N$ & $\sim$ & $N$ \\
\hline 出 & \multicolumn{2}{|l|}{$\underset{\Xi}{0}$} & -1 & $r$ & $\dashv$ & -1 & & $\rightarrow$ & $\rightarrow$ & $\rightarrow$ & -1 & $\rightarrow$ & -1 & $\rightarrow$ & $\rightarrow$ \\
\hline & \multicolumn{2}{|l|}{ 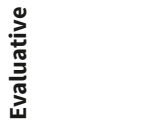 } & $m$ & $m$ & $m$ & $m$ & & $m$ & $m$ & $m$ & $m$ & $m$ & $m$ & $m$ & $m$ \\
\hline \multirow{4}{*}{$\begin{array}{l}\text { ․․ } \\
\text { 은 }\end{array}$} & \multirow{2}{*}{ 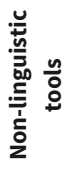 } & வ் & $m$ & $m$ & $m$ & $m$ & & $m$ & $m$ & $m$ & $m$ & $m$ & $m$ & $m$ & $m$ \\
\hline & & ভ్ల & -1 & -1 & -1 & -1 & & $\rightarrow$ & $\rightarrow$ & $\rightarrow$ & -1 & -1 & -1 & $\rightarrow$ & -1 \\
\hline & \multirow{2}{*}{ 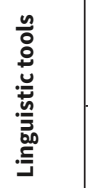 } & $\begin{array}{l}\text { 慈 } \\
\text { 原 }\end{array}$ & 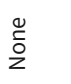 & 芩 & 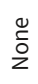 & ஜ̃ & $\frac{0}{\tilde{0}}$ & $\begin{array}{l}0 \\
\stackrel{0}{0} \\
z\end{array}$ & $\begin{array}{l}0 \\
\stackrel{0}{0} \\
\text { ¿ }\end{array}$ & $\begin{array}{l}0 \\
\stackrel{0}{0} \\
z\end{array}$ & $\begin{array}{l}\stackrel{0}{0} \\
\text { ¿े }\end{array}$ & $\begin{array}{l}\stackrel{0}{0} \\
\text { Oे }\end{array}$ & $\begin{array}{l}0 \\
\stackrel{0}{0} \\
z\end{array}$ & $\begin{array}{l}0 \\
\stackrel{0}{0} \\
\text { ¿ }\end{array}$ & $\begin{array}{l}0 \\
\text { ¿ } \\
z\end{array}$ \\
\hline & & $\frac{5}{\sum^{\pi}}$ & $m$ & $m$ & $m$ & $m$ & $m$ & $m$ & $m$ & $m$ & $m$ & $m$ & $m$ & $m$ & $m$ \\
\hline \multicolumn{3}{|l|}{ 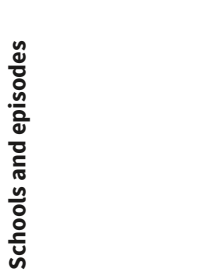 } & 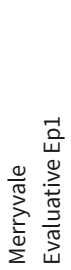 & 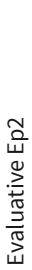 & 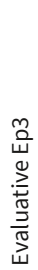 & 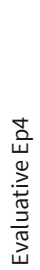 & 总 & 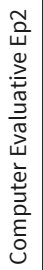 & 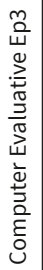 & 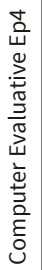 & 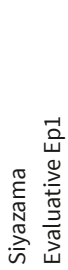 & 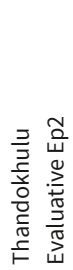 & 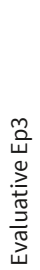 & 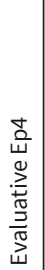 & 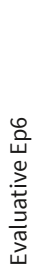 \\
\hline
\end{tabular}


This type of episode is characterised by an Initiate, Respond and Evaluate (IRE) discursive structure that is used to teach, rather than to exclusively test students, and has a didactic form that promotes a relatively high percentage of student verbal interaction. Direct teaching is aimed at the elaboration of mathematical content. Thirteen episodes from the 28 were coded as Type 1 episodes (10 face-to-face and three computer-based lessons). In relation to tool use and evaluative rules, numbers in this table represent levels of elaboration of mathematical content knowledge; [1] represents no elaboration of content and [4] represents high levels of elaboration. In relation to pacing and social rules, the continuum is one of levels of teacher control with [1] representing low levels of teacher control and [4] indicating a very strong degree of teacher control. Division of labour is measured in terms of power relations from symmetrical [1] to asymmetrical [4] relations. Finally objects and their outcomes are measured in terms of whether they refer to localised concrete, practical skills [1] or de-contextualised abstract subject content knowledge [4]. In these episodes teachers use linguistic tools to elaborate [3] mathematical content knowledge. The episodes are characterised by the representational use of tools to elaborate subject content knowledge [3] and a lack of generative use [1] of tools to elaborate mathematics. The evaluative criteria are elaborated [3]. Another feature of instruction in these types of episodes is the relatively low levels of control exercised by the teacher over pacing [1] and social order rules [2]. Somewhat counter-intuitively, however, is the maintenance of strong boundaries between teaching and learning spaces, with the board space serving as a teaching space and the seating area serving as a learning space. This appears as counter intuitive because one would expect less clearly demarcated boundaries between spaces in a classroom where social order rules are more fluid, with students able to engage with and even exercise a degree of control over these rules. However, the elaboration of evaluative criteria in these episodes actually appears to maintain a strong boundary between the teaching and learning space. While teachers enact the role of instructor, which provides for a relatively symmetrical [2] power relation, the rigid boundaries between learning and teaching spaces tend to maintain asymmetries between teachers and taught. The object being worked on in this type of episode is students' understanding of subject content knowledge [3] that develops mathematically literate students.

Type 1 episodes are described in this study as "Reinforcement Pedagogy" (RP) episodes because the object of these episodes is to develop and reinforce students' content knowledge through the use of direct teaching methods. Direct teaching has, unfortunately, become associated with the simple transmission as opposed to meaningful acquisition of knowledge. However, didactic approaches do not necessarily imply a dull transmission of facts but, at their best, these approaches involve children in actively learning concepts (Siraj-Blatchford, 1999). Reinforcement Pedagogy episodes are characterised by structured pedagogic communication in which the teacher guides 
and overtly structures students' engagement with the task through setting up a dialogical space in which structured, cueing questions guide students' engagement.

The second pattern to emerge was episodes characterised by the teacher acting in his/her role of mediator, using linguistic and material tools to develop students' metacognitive ability in relation to mathematics in a context in which evaluative rules are elaborated and social order and pacing rules are weakly controlled by the teacher. Table 6 illustrates the types of patterns of tool use, object, rules, outcome and division of labour identified across the episodes.

In Table 6 below, teachers use tools, such as language and material tools (such as the backboard) to elaborate mathematical subject content knowledge [3-4] but do not often use representational tools to elaborate content [1-2]. Rather, tools serve a predominantly generative function [3]. In these episodes evaluative criteria are elaborated [4]. The teacher exercises weak control over pace [1] and social order rules [1]. These types of episodes demand that students adopt a critical, reflective role [2] in relation to the pedagogic text and even, in one instance, an active enquiring role [1]. The teachers' role in these episodes is one of mediator [1]. This role is characterised by the explicit elaboration of evaluative criteria, the use of mathematical explanations, probing questions and material artefacts as generative tools and the weakening of teacher control over rules of the social order and pacing. Students have a level of control over communication relations. Space in these episodes is not as rigidly demarcated [2] as in the RP episodes and there is some fluidity between learning and teaching spaces. The object of these episodes is the development of specialist knowledge [4].

These episodes are labelled "Collaborative Pedagogy" episodes (CP) because the teacher and students work together to construct a deeper understanding of the pedagogic text. A key feature of these episodes is the teacher's development of students' metacognitive capacity in relation to mathematics. The notion of "metacognition" that informs these types of episodes is drawn from Strohm-Kitchener's (1983) notion of cognitive processing. It refers here to the development of a reflective stance in relation to the work being studied, drawing from Strohm-Kitchener's (1983) three-tiered view of cognitive processing. Pinard (1986) argues that metacognitive control entails knowing both how to do something as well as why one uses specific strategies as opposed to others. So, metacognitive control entails the ability to both do something and theorise or provide reasons for why one has done it. The ability to solve a problem, as well as reflect on or provide reasons for why one solves it in a specific fashion, is a key feature of CP episodes. Students in these episodes are encouraged to develop novel ways of solving problems, provided they can give reasons for how they arrive at their methods. Crucially, metacognitive development requires effective mediation. One sees this in these episodes in terms of the teachers' role, which is one of mediator. Five of the episodes established the pattern identified as collaborative episodes. No computer-based episodes fitted this pattern. 


\begin{tabular}{|c|c|c|c|c|c|c|c|}
\hline 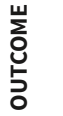 & \multicolumn{2}{|l|}{ 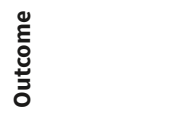 } & $\nabla$ & $\nabla$ & $\sigma$ & $\sigma$ & $\nabla$ \\
\hline $\begin{array}{l}\text { ్ㅐ } \\
\text { ơ }\end{array}$ & \multicolumn{2}{|l|}{ 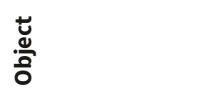 } & $\nabla$ & $\nabla$ & $\nabla$ & $\nabla$ & 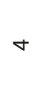 \\
\hline 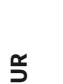 & \multicolumn{2}{|l|}{$\begin{array}{l}\stackrel{\Xi}{\pi} \\
\text { जั }\end{array}$} & $N$ & $\sim$ & $\sim$ & $N$ & $N$ \\
\hline $\begin{array}{l}\frac{0}{4} \\
\frac{1}{4} \\
z \\
z\end{array}$ & \multicolumn{2}{|l|}{ 蒙 } & $\sim$ & $\rightarrow$ & $N$ & $N$ & $N$ \\
\hline$\frac{n}{\bar{a}}$ & \multicolumn{2}{|l|}{ 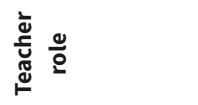 } & $\rightarrow$ & $\dashv$ & $\rightarrow$ & $\neg$ & -1 \\
\hline \multirow{3}{*}{ 岃 } & \multicolumn{2}{|l|}{ 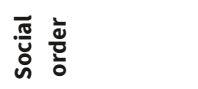 } & $\rightarrow$ & $\neg$ & $\rightarrow$ & $\neg$ & $\rightarrow$ \\
\hline & \multicolumn{2}{|l|}{ ֻّ } & $\neg$ & $\dashv$ & $\rightarrow$ & $\rightarrow$ & $\rightarrow$ \\
\hline & \multicolumn{2}{|l|}{ 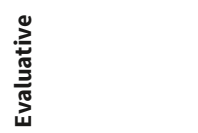 } & $\sigma$ & $\sigma$ & $\sigma$ & 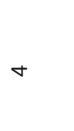 & $\sigma$ \\
\hline \multirow{4}{*}{ 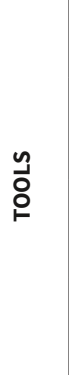 } & \multirow{2}{*}{ 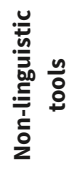 } & ֻั & -1 & $\dashv$ & $\rightarrow$ & $N$ & $N$ \\
\hline & & ฮั & $m$ & $m$ & $\sigma$ & $m$ & $m$ \\
\hline & \multirow{2}{*}{ 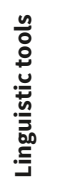 } & $\begin{array}{l}\text { 慈 } \\
\text { 咅 }\end{array}$ & $\begin{array}{l}0 \\
\stackrel{0}{0} \\
z\end{array}$ & 巳ั & 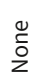 & $\begin{array}{l}0 \\
\stackrel{0}{0} \\
z\end{array}$ & $\begin{array}{l}0 \\
\text { ¿े }\end{array}$ \\
\hline & & $\frac{5}{\frac{\pi}{2}}$ & $\nabla$ & $\sigma$ & $m$ & $\nabla$ & 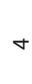 \\
\hline \multicolumn{3}{|c|}{ 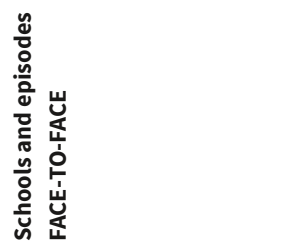 } & 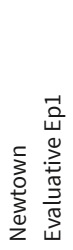 & 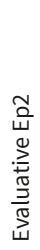 & 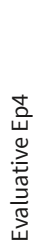 & 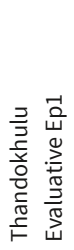 & 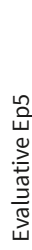 \\
\hline
\end{tabular}


In the third pattern identified in the data, teachers, acting as directors, use computers, other tools and language in order to develop students' technical task skills in a context in which evaluative rules are not elaborated and the teacher exercises strong control over pacing and social order rules. Table 7 illustrates key features of this type of episode.

Very little talk is used to elaborate mathematics [1-2]. Most teacher language is used to elaborate task skills [3]. Material tools are used to represent verbal knowledge visually [3]. These types of episodes are characterised by strong teacher control over pace [4] and social order rules [3], and low levels of elaboration of evaluative criteria [1]. Spatial boundaries are relatively porous, with the teacher moving around the laboratory checking students' work. The teacher's role is "director". This role is characterised by the fact that teacher talk functions as a tool to facilitate students' access to technology through developing their technical task skills. The kind of knowledge being imparted takes the form of technical skills that are localised and situated. That is, these skills appear to be tied to specific task situations and are geared to producing technically proficient students. The pattern identified here is labelled as "Directive Pedagogy" (DIR) because the object being acted on is students' technical task skills and the teacher uses directive tools to accomplish this object. Four computer episodes, two in Merryvale (episodes 2 and 4), one in Newtown (episode 1) and one in Thandokhulu (episode 3) and one face-to-face episode (Merryvale, episode 5) fit this pattern.

The fourth pattern identified in the data are episodes that are characterised by a pattern of practice in which the teacher, acting in his/her role of manager, uses language to regulate students' actions in a context in which evaluative rules are not elaborated and where the teacher exercises a high degree of control over rules of pacing and social order rules. Table 8 provides an overview of pedagogical practices in these episodes.

All the episodes represented in Table 7 are drawn from computer-based episodes. The teacher does not use language as a tool to elaborate mathematical content knowledge in this type of episode [1]. Language use here is highly regulative with social order [4] and pacing [3] rules being strongly controlled by the teacher in a context in which evaluative rules are not elaborated [1]. Rather than serving to elaborate mathematical principles, evaluation appears to serve a pacing function, keeping the lesson moving. The teacher uses no material tools in these episodes. The teaching and learning space is generally very weakly demarcated [1] in these episodes as the teacher does not tend to sit near the computer but rather, moves around the computer laboratory during the episode. Students are verbally passive in these types of episodes and do not occupy much of the talk time (less than $10 \%$ of the overall discourse comprises student utterances). Their roles tend to be as performers [4]. The teacher's role is predominantly to manage students' behaviour [4]. 


\begin{tabular}{|c|c|c|c|c|c|c|c|}
\hline 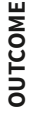 & \multicolumn{2}{|l|}{ 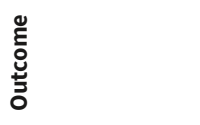 } & $\sim$ & $\sim$ & $N$ & $N$ & $N$ \\
\hline $\begin{array}{l}\text { tu } \\
\text { 㟧 }\end{array}$ & \multicolumn{2}{|l|}{ 苛 } & $\sim$ & $\sim$ & $N$ & $N$ & $N$ \\
\hline \multirow{3}{*}{ 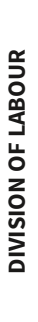 } & \multicolumn{2}{|l|}{$\begin{array}{l}\text { ֻूँ } \\
\text { ñ }\end{array}$} & $\sim$ & $N$ & $N$ & $N$ & $\sim$ \\
\hline & \multicolumn{2}{|l|}{ 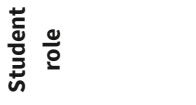 } & $\nabla$ & $\nabla$ & $\nabla$ & $\nabla$ & $\nabla$ \\
\hline & \multicolumn{2}{|l|}{ 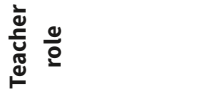 } & $m$ & $m$ & $m$ & $m$ & $m$ \\
\hline & \multicolumn{2}{|l|}{ 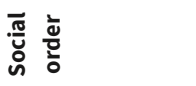 } & $m$ & $m$ & $m$ & $m$ & $m$ \\
\hline 岃 & \multicolumn{2}{|l|}{ జू } & $\nabla$ & $\sigma$ & $\nabla$ & $\nabla$ & $\nabla$ \\
\hline & \multicolumn{2}{|l|}{ 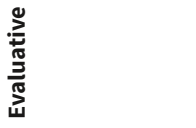 } & $\rightarrow$ & $\rightarrow$ & $\rightarrow$ & $\neg$ & $\rightarrow$ \\
\hline \multirow{4}{*}{ 옹 } & \multirow{2}{*}{ 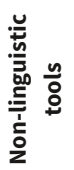 } & $\dot{\stackrel{亠}{\Xi}}$ & $m$ & $m$ & $\rightarrow$ & $m$ & $m$ \\
\hline & & ভ్ల & $\rightarrow$ & $\rightarrow$ & $\rightarrow$ & $\neg$ & $\rightarrow$ \\
\hline & \multirow{2}{*}{ 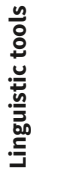 } & 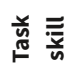 & $m$ & $m$ & $m$ & $m$ & $m$ \\
\hline & & $\frac{5}{\frac{\pi}{2}}$ & $\sim$ & $N$ & $\neg$ & $\sim$ & $\sim$ \\
\hline \multicolumn{3}{|l|}{ 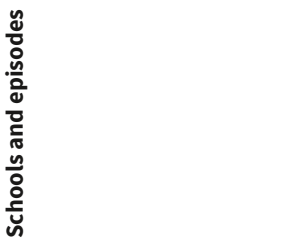 } & 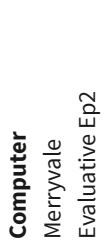 & 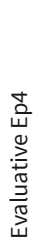 & 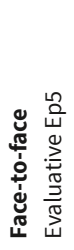 & 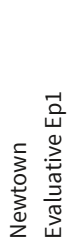 & 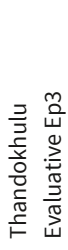 \\
\hline
\end{tabular}




\begin{tabular}{|c|c|c|c|c|c|c|c|}
\hline 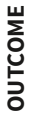 & \multicolumn{2}{|l|}{ 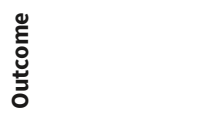 } & $\rightarrow$ & -1 & $\neg$ & $\neg$ & $\rightarrow$ \\
\hline $\begin{array}{l}\text { ్ㅐ } \\
\text { 。̋ }\end{array}$ & \multicolumn{2}{|l|}{ 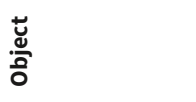 } & $\rightarrow$ & -1 & $\neg$ & $\rightarrow$ & -1 \\
\hline 号 & \multicolumn{2}{|l|}{ 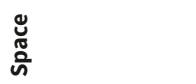 } & $\neg$ & -1 & $\neg$ & $\neg$ & -1 \\
\hline $\begin{array}{l}\text { 岁 } \\
\text { u } \\
z \\
z\end{array}$ & \multicolumn{2}{|l|}{ 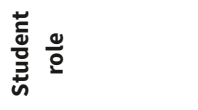 } & $\nabla$ & $\sigma$ & $\nabla$ & $\nabla$ & ナ \\
\hline \} $&{\multicolumn{2}{|l|}{\text { 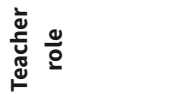 }}\text { 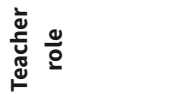 }} &{\sigma} &{\sigma} &{\sigma} &{\sigma} &{\nabla} \\
{\hline \multirow{3}{*}{\text { 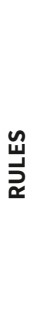 }}\text { 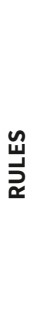 }} &{\multicolumn{2}{|l|}{\text { 坖 }}\text { 坖 }} &{m} &{m} &{m} &{m} &{m} \\
{\hline} &{\multicolumn{2}{|l|}{\underset{\Xi}{\mathbb{g}}}\underset { \Xi } { \mathbb { g } }} &{\nabla} &{\nabla} &{\nabla} &{\nabla} &{\nabla} \\
{\hline} &{\multicolumn{2}{|l|}{\text { 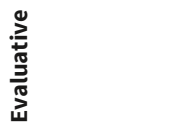 }}\text { 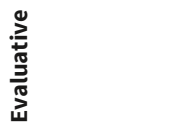 }} &{\rightarrow} &{\rightarrow} &{\neg} &{\rightarrow} &{-1} \\
{\hline \multirow{4}{*}{\text { ֻّ }}\text { ֻّ }} &{\multirow{2}{*}{\text { 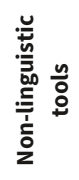 }}\text { 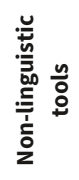 }} &{\frac{\dot{\alpha}}{\ddot{0}}} &{\text { 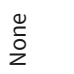 }} &{\begin{array}{l}\stackrel{0}{0} \\
\stackrel{0}{2}\end{array}} &{\text { 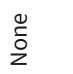 }} &{\begin{array}{l}\stackrel{0}{2} \\
\stackrel{0}{z}\end{array}} &{\text { 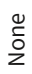 }} \\
{\hline} &{ } &{\text { ভ్ }} &{\frac{\dddot{0}}{\check{0}}} &{\frac{0}{\check{0}}} &{\frac{\dddot{0}}{\check{0}}} &{\text { 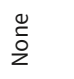 }} &{\text { : }} \\
{\hline} &{\multirow{2}{*}{\text { 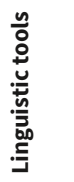 }}\text { 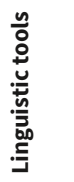 }} &{\begin{array}{l}\text { 岛 } \\
\text { 点 }\end{array}} &{\sim} &{\text { N }} &{\neg} &{N} &{-1} \\
{\hline} &{ } &{\frac{5}{\sum}} &{\rightarrow} &{\rightarrow} &{\neg} &{\rightarrow} &{-1} \\
{\hline \multicolumn{3}{|l|}{\text { 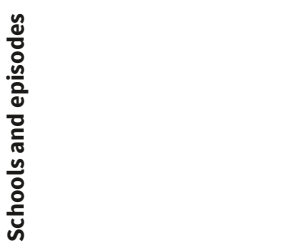 }}\text { 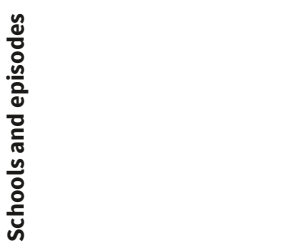 }} &{\text { 空 }} &{\text { 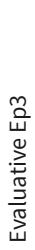 }} &{\text { 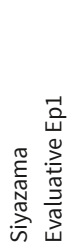 }} &{\text { 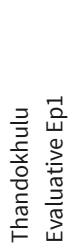 }} &{\text { 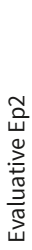 }} \\
$\hline
\end{tabular}

PINS [Psychology in Society] 48. 2015|68 
Drawing on Garrison and Bromley (2002) these episodes are labelled "Defensive pedagogy" (DP) episodes because they are characterised by teachers tightening control over students' actions as a means to defend and maintain asymmetrical power relations in the class. There is very little student verbal interaction in these episodes and teachers primarily focus on regulating students' behaviour. Five of the recorded 28 episodes were categorised as Defensive pedagogy episodes and all were computer-based episodes. Three of the four schools taking part in the study had episodes that fall into this category. DP episodes are characterised by high incidences of behavioural prescriptions and low incidences of mathematical explanations. There are few if any mathematical utterances in these types of episodes and the object of the episodes is a regulative, rather than an instructional one.

Table 9. Pedagogic type

across face to face and computer based mathematics lessons

\begin{tabular}{|c|c|c|c|c|c|c|c|c|c|}
\hline \multirow[t]{3}{*}{ Type of episode } & \multicolumn{9}{|c|}{ Schools } \\
\hline & \multicolumn{2}{|c|}{ Merryvale } & \multicolumn{2}{|c|}{ Thandokhulu } & \multicolumn{2}{|c|}{ Siyazama } & \multicolumn{2}{|c|}{ Newtown } & \multirow[t]{2}{*}{ Total } \\
\hline & Comp & F2f & Comp & F2f & Comp & F2f & Comp & F2f & \\
\hline $\begin{array}{l}\text { Reinforcement } \\
\text { pedagogy }\end{array}$ & & 4 & & 4 & & 1 & 3 & 1 & 13 \\
\hline $\begin{array}{l}\text { Collaborative } \\
\text { pedagogy }\end{array}$ & & & & 2 & & & & 3 & 5 \\
\hline $\begin{array}{l}\text { Defensive } \\
\text { pedagogy }\end{array}$ & 2 & & 2 & & 1 & & & & 5 \\
\hline $\begin{array}{l}\text { Directive } \\
\text { pedagogy }\end{array}$ & 2 & 1 & 1 & & & & 1 & & 5 \\
\hline
\end{tabular}

In Table 9 one can see that face to face pedagogy is characterised by reinforcement pedagogy, whose object is the reinforcement of students' content knowledge. Directive and collaborative pedagogy feature strongly after reinforcement pedagogy in face to face lessons. Of interest is the fact that collaborative pedagogy is completely absent from the computer based mathematics lessons. This is contrary to the studies reviewed earlier in the paper where the computer, for example, can develop autonomous students who engage in exploratory talk (see for example the work of Mercer and Wegeriff). 
Collaborative pedagogy is characterised by a focus on developing reflective mathematical understanding and metacognitive control as its object; it is therefore, troubling that we find no instances of this pedagogical type in the computer based lessons. One possible reason for this lies in the software used in these schools. CAMI maths, the software used in these schools, can indeed be used to scaffold, or guide students' engagement with higher order concepts, however, it can also be used as a drill and practice tool. What distinguishes the use is not the software, but the teacher: where pacing is tightly controlled by the teacher and all students are required to work at the same pace (as in directive or defensive pedagogy) the software will only serve as a drill and practice tool as no space is made for individual pacing. One is therefore, not in a position to critique the software in this instance; the answer for the dearth of collaborative and reinforcement pedagogy lies in the tightening of regulative and instructional rules in the computer based lesson. Reasons for this were clear from the teachers' demographic questionnaires as well as from their interviews. Only one teacher had a computer at home; hence, only one teacher was even fairly well versed in using the technology. Teachers had been given only two hours training on how to use the computers and the software, leaving them feeling, according to Mrs De Wet: "Ja, uhm, the children you know, I think they know more than me sometimes. On the computer" (Mrs De Wet: 3: 12). Further, the fact that directive pedagogy predominates in computer based lessons needs to be seen against the relative lack of training teachers and students have in technically using the computers. Once teachers and students are more immersed in the technology, one would expect this picture to shift. It will be interesting to note, in fact, the extent to which this happens.

\section{Conclusion}

For Vygotsky (1978) mind is essentially social; what beings as interpersonal relations between a culturally more competent other and a novice become internalised as actual higher cognitive functions by the novice. This is nowhere more evident than at the micro level of the school classroom. It is here, in this space that uniquely human psychological tools are mediated to students, impacting on their developmental trajectories. If we are to fully understand psychological development, then we need to look to pedagogical practices to see how they impact development. The dialectical logic of CHAT allows us to directly place mind in society, overcoming the traditional Western binary logic that focuses on individual/social. For this reason, the paper draws on CHAT to understand pedagogical modes emerging out of teaching with technology. This paper investigated the extent to which pedagogy varies in the presence of computers in 4 disadvantaged primary schools in the Western Cape province of South Africa. The paper draws heavily on Vygotksian and Neo-Vygotskian work in the field of Cultural Historical Activity Theory, relying ultimately on the work of Engeström (1987) to understand how pedagogical practices shift in the presence of computers along specific CHAT lines, such as subject, object, tools, rules, division of labour and community. Four ideal types of pedagogy were

PINS [Psychology in Society] 48, $2015 \mid 70$ 
observed in the data: reinforcement pedagogy which characterised face to face lessons and had reinforcement of content knowledge as its object; collaborative pedagogy, observed only in face to face lessons, and having the development of students' metacognitive reflection as its object; directive pedagogy which characterised computer based lessons and had technical skills as its object and finally, defensive pedagogy which had a regulative object. The dearth of collaborative and reinforcement pedagogical practices in the computer based lesson is concerning, given the object of computer based mathematics lessons is supposed to be the development of content knowledge, at the very least. This is not to suggest that computers add no value to student attainment; clearly there is sufficient research in that area to indicate that they do. The suggestion here is that one needs to understand the context into which computers are placed and, more critically, to unpack how computers are used by teachers in their teaching. This paper represents an attempt to speak to this issue.

\section{References}

Au, W K \& Leung, J P (1991) Problem solving, instructional methods and Logo programming. Journal of Educational Computing Research, 7(4), 455-467.

BECTA (2000) ImpaCT2: Emerging findings from the evaluation of the impact of information and communications technologies on pupil attainment. Retrieved 28 September 2003. http://www.becta.org.uk/research/reports/impact2/index.html.

BECTA (2001) Primary schools of the future achieving today. A report to the DFEE. Retrieved 24 January 2004. http://www.becta.org.uk.

BECTA (2007) Annual review. Retrieved 3 July 2007. http://www.becta.org.uk

Bernstein, B (1977) Class, codes and control. Volume 3: Towards a theory of educational transmissions. London: RKP.

Campbell, P F, Fein, G G \& Schwartz, S S (1991) The effects of Logo experience on first grade children's ability to estimate distance. Journal of Educational Computing Research, 7(3), 331-349.

Cobb, P \& McClain, K (2002) Supporting students learning of significant mathematical ideas, in Wells, $G$ \& Claxton, $G$ (eds) Learning for life in the $\mathbf{2} 1^{\text {st }}$ century. Oxford: Blackwell (pp 154-167).Cox, M J \& Abbott, C (eds) (2004) ICT and attainment: A review of the research literature. Coventry: Becta / London: DfES. 
Department of Basic Education (2013) Annual National Assessment: 2013 Diagnostic Report and 2014 Framework for Improvement. Retrieved 3 July 2014. http://www. education.gov.za/LinkClick.aspx?fileticket=50lPtO90kr0\%3D\&tabid=422\&mid=1325

Donovan, L, Hartley, K \& Strudler, N (2007) Teacher concerns during initial implementation of a one-to-one laptop initiative at the middle school level. Journal of Research on Technology in Education, 39(3), 263-286.

Engeström, Y (1987) Learning by expanding: An activity -theoretic approach to developmental research. Helsinki: Orienta-KonsultitOy.

Engeström, Y (1990) Learning, working and imagining twelve studies in activity theory. Helsinki: Orienta-KonsultitOy.

Engeström, Y (1991) Non scolaesed vitae discimus: Toward overcoming the encapsulation of school learning. Learning and Instruction, 1, 243- 259.

Engeström, Y (1996) Perspectives on activity theory. Cambridge: Cambridge University Press.

Engeström, Y (1999) Activity Theory and individual and social transformation, in Engeström, Y, Miettinen, R \& Punamaki, R L (eds) Perspectives on Activity Theory. Cambridge: Cambridge University Press (pp 19-38).

Flanagan, J C( 1954) The critical incident technique. Psychological bulletin, 5(14), 327-358.

Garrison, M J \& Bromley, H (2004) Social contexts, defensive pedagogies, and the (mis) uses of educational technology. Educational Policy, 18(4), 589-613.

Goodwin, P (ed) (2001) The articulate classroom. London: David Fulton.

Hardman, J (2005a) Activity Theory as a potential framework for technology research in an unequal terrain. South African Journal of Higher Education, 19(2), 378-392.

Hardman, J (2005b) An exploratory case study of computer use in a primary school mathematics classroom: New technology new pedagogy?

Perspectives in Education, 23(4), 1-13. 
Hardman, J (2005c) Activity Theory as a framework for understanding teachers' perceptions of computer usage at a primary school level in South Africa. South African Journal of Education, 25(4), 258-265.

Hardman, J (2007a) Towards a methodology for using Activity Theory to explicate the pedagogical object in a primary school mathematics classroom. Outlines, 1, 53-69.

Hardman, J (2014) Form and function of questions across computer and face to face based lessons: A sociocultural analysis. Standard Global Journal of Educational Research, 1(2), 25- 32.

Hakkarainen, K (2003) Progressive inquiry in a computer-supported biology classroom. Journal of Research in Science Teaching, 40(10), 1072-1088.

Hakkarainen, K (2004) Pursuit of explanation within a computer-supported classroom. International Journal of Science Education, 26(8), 979-996.

Hedegaard, M \& Fleer, M (2008) Studying children: A cultural-historical approach. London: Open University Press.

Hokanson, B \& Hooper, S (2000) Computers as cognitive media: Examining the potential of computers in education. Computers in Human Behaviour, 16(1), 537-552.

Hoyles, C \& Sutherland, R (1989) Logo mathematics in the Classroom. London: Routledge.

Ilomäki, L, Lakkala, M, \& Lehtinen, E (2004) A case study about ICT adoption within a teacher community at a Finnish lower secondary school. Education, Communication \& Information, 4(1), 53-69.

Ilomäki, L, Lakkala, M, \& Paavola, S (2006) Case studies of learning objects used in school settings. Learning, Media, and Technology, 31(3), 145-160.

Khanya Technology in education project (nd) Summary. Retrieved 12 July 2015. http:// wced.pgwc.gov.za/documents/abuse no more/summary document/khanya.html

Kozma, R B, \& Anderson, R E (2002) Qualitative case studies of innovative pedagogical practices using ICT. Journal of Computer Assisted Learning, 18, 387-394.

Leontiev, A N (1978) Activity, consciousness, and personality.

Englewood Cliffs, NJ: Prentice-Hall. 
Leontiev, A N (1981) The problem of activity in psychology, in Wertsch, J V (ed) The concept of activity in Soviet psychology. Armonk, NY: M E Sharpe.

McNeil, L M (1986) Contradictions of control: School structure and school knowledge. New York: Routledge \& Kegan Paul.

Mercer, N, \& Fisher, E (1997a) Scaffolding through talk, in Wegerif, R \& Scrimshaw, P (eds) Computers and talk in the primary classroom. Clevedon: Multilingual Matters.

Mercer, N, \& Fisher, E (1997b) The importance of talk, in Wegerif, R \& Scrimshaw, P (eds) Computers and talk in the primary classroom. Clevedon: Multilingual Matters.

Mercer, N, \& Wegerif, R (1998) Is “exploratory talk" productive talk?, in Littleton, $K$ \& Light, $P$ (eds) Learning with computers: Analysing productive interactions. London: Routledge.

Mercer, N, Wegerif, R, \& Dawes, L (1999) Children's talk and the development of reasoning in the classroom. British Educational Research Journal, 25(1), 95-111.

Mercer, N (2000a) How is language used as a medium for classroom education?, in Moon, B, Brown, S \& Ben-Perez, M (eds) The Routledge international companion to education . London: Routledge.

Mercer, N (2000b) Words and minds: How we use language to think together. London: Routledge.

Mercer, N (2005) Sociocultural discourse analysis: analysing classroom talk as a social mode of thinking. Journal of Applied Linguistics, 1(2), 137-168.

Miettinen, R (1999) Transcending traditional school learning, in Engeström, Y. Miettinen, R \& Punamaki, R-L (eds) Perspectives in activity theory. Cambridge: Cambridge University Press.

Mouza, C (2008) Learning with laptops: Implementation and outcomes in an urban, under-privileged school. Journal of Research on Technology in Education, 40(4), $447-473$.

Ogbu, J U (1987) Variability in minority school performance: A problem in search of an explanation. Anthropology and Education Quarterly, 18(4), 312-334. 
Paavola, S, \& Hakkarainen, K (2005) The knowledge creation metaphor: An emergent epistemological approach to learning. Science \& Education, 14, 535-557.

Ridgway, A, Quinones, G \& Liang, L (2015) Early childhood pedagogical play. London: Springer.

Roth, W-M, \& Lee, Y-J (2007) Vygotsky's neglected legacy: Cultural-historical activity theory. Review of Educational Research, 77, 186-232.

Russell, D (2002) Looking beyond the interface: Activity Theory and distributed learning, in Lea, M \& Nicoll, K (eds) Distributed learning. London: Routledge.

Saljo, R (1999) Learning as the use of tools: A Socio-cultural perspective on the human technology link, in Littleton, $K$ \& Light, $P$ (eds) Learning with computers: Analysing productive interaction. London: Routledge.

Schollar, E (2001) A review of two evaluations of the application of the READ Primary Schools Programme in the Eastern Cape Province of South Africa. International Journal of Educational Research, 35, 205-216.

Spaull, N (2014) Education rankings: There's madness in WEF methods.

Mail \& Guardian. Retrieved 2 July 2104. http://mg.co.za/article/2014-06-13-theresmadness-in-wef-methods

Spencer-Smith, G \& Hardman, J (2014) The impact of computer and mathematics software usage on performance of school leavers in the Western Cape Province of South Africa: A comparative analysis. International Journal of Education and Development using ICT, 10(1), 22-40.

Stetsenko, A (2013). Theorizing personhood for the world in transition and change: Reflections from a transformative activist stance, in Martin, J \& Bickhard, M H(eds) The psychology of personhood: Philosophical, historical, social-developmental, and narrative perspectives. Cambridge: Cambridge University Press.

Underwood, J D M \& Underwood, G (1990) Computers and learning: Helping children acquire thinking skills. Oxford: Basil Blackwell Ltd.

Underwood, J D M \& Underwood, G (1999) Task effects on collaborative learning, in Littleton, $\mathrm{P}$ \& Light, $\mathrm{S}$ (eds) Learning with computers: Analysing productive interaction. London: Routledge. 
Veermans, M, \& Cesareni, D (2005a) The nature of the discourse in collaborative virtual learning: Case studies from four different countries.

Computers \& Education, 45(3), 316-336.

Veermans, M, Lallimo, J, \& Hakkarainen, K (2005b) Patterns of guidance in inquiry learning. Journal of Interactive Learning Research, 16(2), 179-194.

Vygotsky, L S (1978) Mind in society. The development of higher psychological processes. Cambridge, MA: Harvard University Press.

Vygotsky, L S (1986) Thought and language. Cambridge, MA: MIT Press.

Vygotsky, LS (1997b) Educational psychology. Boca Ratan: St Lucie Press.

Wegerif, R, \& Mercer, N (1997) Using computer-based analysis to integrate quantitative and qualitative methods in the investigation of collaborative learning. Language and Education, 11(4), 271-286.

Wegerif, R, \& Dawes, L (1997) Computers and exploratory talk: An intervention study, in Wegerif, R \& Scrimshaw, $\mathrm{P}$ (eds) Computers and talk in the primary classroom. Clevedon: Multilingual Matters.

Wegerif, R, \& Mercer, N (1997c) A dialogical framework for investigating talk, in Wegerif, $\mathrm{R} \&$ Scrimshaw, $\mathrm{P}$ (eds) Computers and talk in the primary classroom. Clevedon: Multilingual Matters.

Wegerif, R \& Scrimshaw, P (1997d) Introduction: Computers, talk and learning', in Wegerif, $R$ \& Scrimshaw, $P$ (eds) Computers and talk in the primary classroom. Clevedon: Multilingual Matters.

Wells, G (1999) Dialogic inquiry: Towards a socio-cultural practice and theory of education. Cambridge: Cambridge University Press.

Wragg, E (2001) Assessment and learning in the primary school. New York: Routledge.

Yelland, N (2003) Young children learning with Logo: An analysis of strategies and interactions. Journal of Educational Computing Research, 9(4), 465-486.

Yin, R K (1984) Case study research: Design and methods.

Beverly Hills, CA: Sage Publications. 